\section{Molecular typing of Staphylococcus aureus isolate responsible for staphylococcal poisoning incident in home- made food}

\author{
Guerrino Macori, 1,2 Alberto Bellio,, \\ Daniela Manila Bianchi, ${ }^{1}$ Silvia Gallina, ${ }^{1,2}$ \\ Daniela Adriano, ${ }^{1}$ Fabio Zuccon, ${ }^{1,2}$ \\ Francesco Chiesa, ${ }^{3}$ Pier Luigi Acutis, ${ }^{1}$ \\ Francesco Casalinuovo, ${ }^{4}$ \\ Lucia Decastelli ${ }^{1,2}$ \\ ${ }^{1}$ Institute for Experimental Veterinary \\ Medicine of Piedmont, Liguria and Aosta \\ Valley, Turin; ${ }^{2}$ Italian Reference \\ Laboratory for Coagulase Positive \\ Staphylococci including S. aureus, \\ Institute for Experimental Veterinary \\ Medicine of Piedmont, Liguria and Aosta \\ Valley, Turin; ${ }^{3}$ Department of Animal \\ Pathology, University of Turin, Grugliasco \\ (TO); ${ }^{4}$ Institute for Experimental \\ Veterinary Medicine of Southern Italy, \\ Catanzaro, Italy
}

\section{Abstract}

In October 2012, two persons fell ill with symptoms consistent with staphylococcal food poisoning after eating home-canned tuna fish and tomatoes. Laboratory investigation detected the enterotoxins in the home-canned tuna and molecular analysis of the isolated Staphylococcus aureus confirmed it carried toxin genes. Qualitative enzyme-linked immunosorbent assay and enzime linked fluorescent assay methods and quantitative assay identified the enterotoxins in the food leftovers, specifically staphylococcal enterotoxins type A (SEA) and D (SED), respectively 0.49 and $2.04 \mathrm{ng} / \mathrm{g}$. The laboratory results are discussed considering the relation to the fish in oil, survival and heat resistance of $S$. aureus, and presumptive microbial contamination due to improper handling during home-canning procedures. This is the first reported cluster of foodborne illnesses due to staphylococcal enterotoxins in tuna in Italy. In this study, we reported cases described and analysed for their $s p a$-type. Showing a high heterogeneity of isolates, spa-type $t 13252$ is correlated in a node of the minimum spanning tree and it has never been reported as responsible for foodborne outbreak. This case underlines the importance of risk communication and dissemination of home-canning guidelines to reduce the incidence of foodborne outbreaks caused by homemade conserves.

\section{Introduction}

Staphylococcal food poisoning (SFP), a frequent cause of foodborne diseases worldwide, occurs following the ingestion of staphylococcal enterotoxins (SEs) produced by enterotoxigenic strains of coagulase-positive staphylococci, particularly Staphylococcus aureus (Bianchi et al., 2014). In 2012, SEs were responsible for 346 foodborne outbreaks (FBOs) in the European Union, representing $6.4 \%$ of all outbreaks reported in the EU. These figures are consistent with those of the previous year, 2011, when 345 outbreaks were reported. Foodborne outbreaks due to SEs are frequently represented by mixed foods (31.4\%), followed by cheese $(20.0 \%)$, broiler meat and products thereof $(8.6 \%)$, pig meat and products thereof (5.7\%); while, to our knowledge, fish and fishery products have not been reported as source of SFP (EFSA, 2013, 2014). The incubation period varies depending on the amount of toxins ingested and individual susceptibility. The duration of illness is short and often self-limited. SFP results from the ingestion of improperly prepared or stored foods in which toxins produced by $S$. aureus ( $>5 \log \mathrm{CFU} / \mathrm{g}$ ) are present. In order to type $S$. aureus responsible for $\mathrm{FB} 0$, different techniques are established; the most widely used method for this type of epidemiological investigations is $s p a$-typing, based on the determination of the polymorphic $\mathrm{X}$ region of the gene encoding staphylococcal protein A ( $s p a)$. In this study, we report the results of the investigation of a foodborne outbreak caused by SEs in contaminated home-canned tuna fish occurred in October 2012 in Catanzaro and we compare the strain isolated in 32 strains responsible for other outbreaks published, with the aim of determining the relationship between $S$. aureus isolated strains in FBO cases.

\section{Materials and Methods}

\section{Outbreak investigation and sampling}

In the middle of October 2012, four members of a family (parents and two daughters aged 11 and 16 years) ate home-canned tuna fish preserved in olive oil, which had been received as a gift from a friend. About 3 hours later, the two girls developed nausea, abdominal cramps, vomiting and diarrhea. They were taken to the emergency room of a local hospital for diagnosis and treatment where they were subsequently admitted to the Pediatrics Department for observation. The hospital did not collect stool or vomit samples; however, it notified the surveillance system for foodborne outbreaks which, jointly with the local veteri-
Correspondence: Guerrino Macori, Italian National Reference Laboratory for Coagulase Positive Staphylococci including $S$. aureus, Institute for Experimental Veterinary Medicine of Piedmont, Liguria and Aosta Valley, via Bologna 148, 10154 Turin, Italy.

Tel. +39.011.2686233 - Fax: +39.011 .2473450 .

E-mail: guerrino.macori@gmail.com

Conflict of interest: the authors declare no potential conflict of interest.

Key words: Staphylococcus aureus; Foodborne pathogen; Outbreak investigation; Molecular typing; Spa-typing.

Acknowledgements: the authors thank the European Union Reference Laboratory for providing Coagulase Positive Staphylococci (EURL CPS), including Staphylococcus aureus (MaisonsAlfort Laboratory for Food Safety, Maisons-Alfort, France) for quantification analysis of staphylococcal enterotoxins.

Received for publication: 12 January 2016. Revision received: 27 February 2016.

Accepted for publication: 28 February 2016.

This work is licensed under a Creative Commons Attribution-NonCommercial 4.0 International License (CC BY-NC 4.0).

CC Copyright G. Macori et al., 2016

Licensee PAGEPress, Italy

Italian Journal of Food Safety 2016; 5:5736

doi:10.4081/ijfs.2016.5736

nary and public health services, collected samples of the leftovers.

Enumeration of coagulase-positive staphylococci, phenotypic characterisation of Staphylococcus aureus and detection of staphylococcal enterotoxins in food samples

A food sample was sent to the Institute for Experimental Veterinary Medicine of Southern Italy, Catanzaro. Laboratory analysis of the home-canned tuna included isolation and identification of coagulase-positive staphylococci strains, screening for SEs by means of VIDAS SET2 (BioMérieux, Craponne, France) and for Clostridium botulinum and its neurotoxins (CDC, 1998). The VIDAS SET2 is an automatic qualitative test performed on VIDAS instruments and is based on an enzyme linked fluorescent assay (ELFA) technique for the detection of classical SEs [staphylococcal enterotoxins type A to type E (SEA to SEE)] in food. A food sample was sent to the Italian National Reference Laboratory for coagulasepositive staphylococci (CPS), including $S$. aureus (ITNRL-CPS) in Turin, where confirmatory analyses of SEs were performed according 
to the European Screening Method of the European Reference Laboratory (EU-RL) for CPS-ver. 5 (Ostyn et al., 2010b). The EU-RL for CPS quantified the SEs (types SEA to SEE) using a quantitative enzyme-linked immunosorbent assay (ELISA) (Ostyn et al., 2010a). Coagulase-positive staphylococci were counted in sample using the standard method EN ISO 6888 part 2 (ISO, 1999). Coagulasepositive staphylococci isolate were confirmed by real time using the $\operatorname{TaqMan}^{\circledR}$ Staphylococcus aureus detection kit (Applied Biosystems, Foster City, CA, USA) and biotyped as described by Devriese (1984).

\section{Polymerase chain reactions and detection of virulence genes}

Polymerase chain reaction assays were carried out on the isolated strains to detect the genes encoding SEs (Ostyn et al., 2010a), methicillin resistance $(m e c \mathrm{~A})$, and PantonValentine Leukocidin ( $p v l$ ) (Lamand et al., 2012). In addition the polymorphic $X$ region of the protein $A$, gene spa was sequenced to assign the spa-type (Harmsen et al., 2003).

\section{Cluster analysis of isolates spa-type involved in foodborne poisoning}

Since 2009 in Europe spa-types of isolates involved in cases of SFP were reported. Thirtytwo isolates were analyzed and used for cluster analyses of spa sequences, including the isolates induced the poisoning described in this work and 15 strains related to an additional case (SFP ID 31) (Table 1). The sequences were compared and aligned using an algorithm-based model for pairwise alignment of repeats (default cost matrix in Bionumerics), used to make a minimum spanning tree (MST) setting the bin grouping distance at $1.00 \%$.

\section{Results}

\section{Investigation and epidemiological information}

The two girls developed symptoms about 3 hours after eating the meal. Food history interviews with the family yielded that during the 8 hours preceding symptoms onset the girls had eaten only one meal (consisting of tomatoes and the home-canned tuna fish). Unopened jars were not present when local authorities went to the cooker's house.

\section{Toxins in sample}

The tuna sample resulted positive for staphylococcal enterotoxins and negative for Clostridium botulinum and its toxins. Quantitative ELISA confirmed the presence of toxins (Table 2$)$, specifically SEA $(0.49 \mathrm{ng} / \mathrm{g})$ and SED $(2.04 \mathrm{ng} / \mathrm{g})$.

\section{Typing and molecular analysis}

The isolated $S$. aureus strain resulted negative for mecA and $p v l$, positive for sea, sed, sei, $s e l j$, and ser genes. Spa-typing revealed a new $s p a$-type ( $t 13252)$ and phenotypic characterisation by biotyping showed that the strain was of human origin. This is due to the combination of the results of the biotyping system for $S$. aureus strains proposed by Devriese (1984). It differentiates strains from man and animals into host-specific ecovars and biotypes, which are not host-specific, with the help of tests for haemolysin, staphylokinase, coagulation of bovine plasma and the crystal-violet reaction.

\section{Cluster analysis of isolates involved in foodborne poisoning}

Cluster analysis with BioNumerics software ver. 7.1 (Applied Maths, Sint-Martens-Latem, Belgium) was applied to generate an MST representing the 32 isolates involved in FBO cases reported since 2009 (Figure 1). Twenty-five out of 32 isolates were recorded; the branch length and distance show the genomic relation.

\section{Discussion}

Unopened jars were not present when local authorities went to the cooker's house; they had already been eaten or distributed as gifts. Given the rapid onset of symptoms and considering the characteristics of the food preparation process, the home-canned tuna was suspected as the intoxication cause, although nobody else was reported to be ill, probably due to a non-homogeneous meat contamination among the jars.

Scombroid poisoning was initially considered a likely cause of the outbreak because this type of poisoning with a short incubation period is most frequently associated with tuna and similar fish. The scombroid poisoning, or more accurately defined as histamine food poisoning, can occur after the consumption of spoiled tuna fish where bacteria metabolise histidine into histamine when fish is not kept at refrigerator temperatures (Feng et al., 2016). The symptoms of histamine food poisoning include tongue dysesthesias, face and torso flushing, and a throbbing headache; it often progresses to diarrhea, nausea and vomiting (Wilson et al., 2012; McCarthy et al., 2015). In this case, no allergic reactions were noted, and the gastrointestinal complaints developed about 3 hours after the meal. As the course of symptoms of histamine food poisoning is rapid, within minutes to $30 \mathrm{~min}$, it did not seem a likely cause and histamine levels were not measured.

In 2011, the majority of strong evidence out-

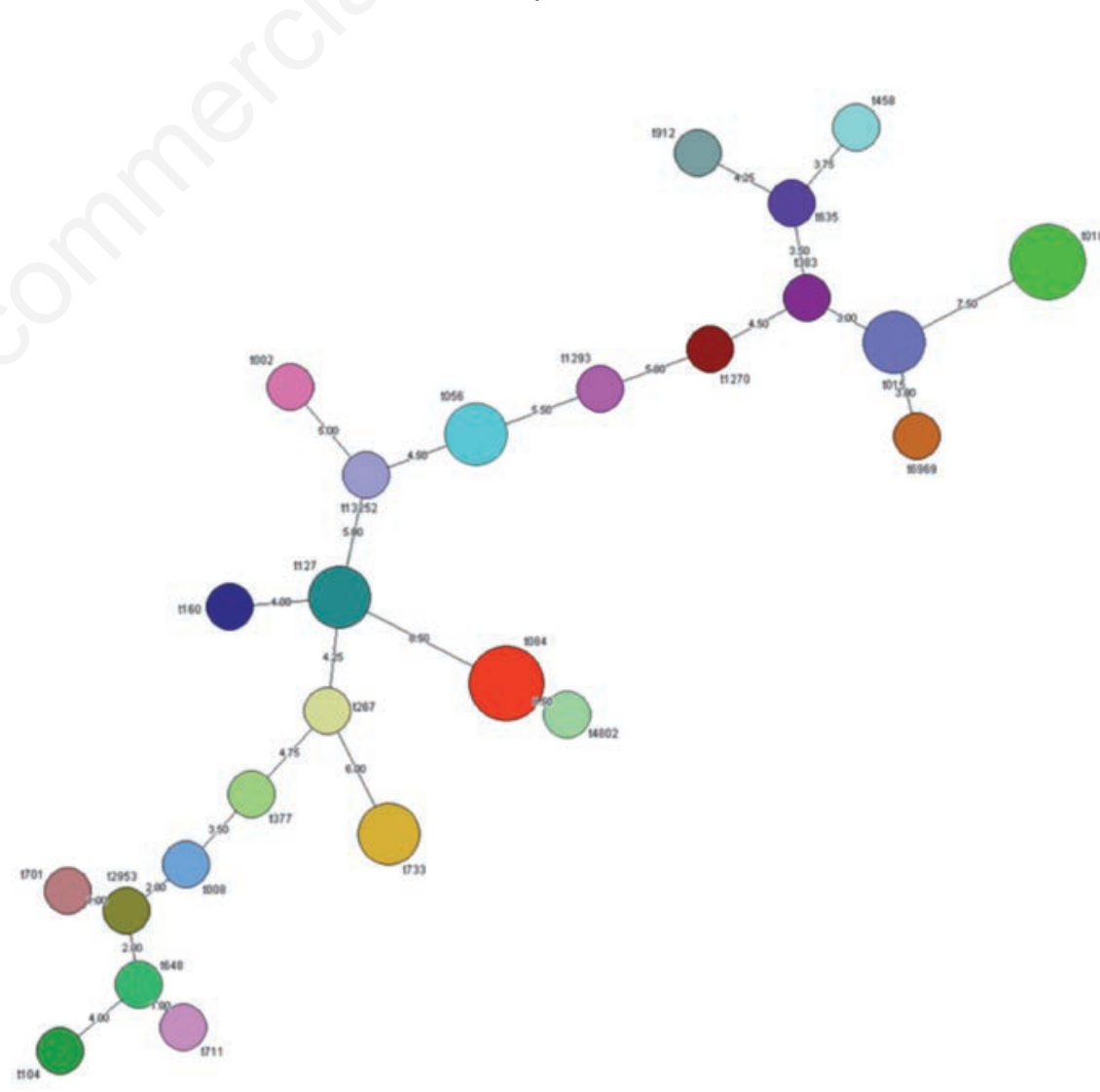

Figure 1. Minimum spanning tree showing the results of the $s p a$ clustering analysis. Twenty-five isolates formed the cluster. The branch length and spa type are shown. 
Table 1. Report of Staphylococcus aureus isolated.

\begin{tabular}{|c|c|c|c|c|c|c|c|c|c|c|}
\hline & SFP ID & Origin & Detail & spa-type & $\begin{array}{l}\text { Phenotypic } \\
\text { characteristics }\end{array}$ & $\begin{array}{c}\text { Genotypic } \\
\text { characteristics }\end{array}$ & $\begin{array}{c}\text { Geographical S } \\
\text { ID s] }\end{array}$ & $\begin{array}{l}\text { Suspec } \\
\text { spreadi }\end{array}$ & $\begin{array}{c}\text { Causative } \\
\text { agent }\end{array}$ & $\begin{array}{l}\text { People } \\
\text { involved }\end{array}$ \\
\hline 5 & $\begin{array}{l}2 \\
3\end{array}$ & $\begin{array}{l}\text { Human } \\
\text { Human } \\
\text { Human } \\
\text { Human } \\
\text { Human } \\
\text { Food } \\
\text { Food } \\
\text { Food } \\
\text { Food } \\
\text { Food }\end{array}$ & $\begin{array}{c}\text { Case, stool } \\
\text { Case, stool } \\
\text { Case, stool } \\
\text { Case,vomit } \\
\text { Nasal swab } \\
\text { Ice-cream vanilla } \\
\text { Ice-cream strawberry } \\
\text { Ice-cream chocolate } \\
\text { Ice-cream pistachio } \\
\text { Ice-cream yoghurt-lemon }\end{array}$ & $\begin{array}{l}\mathrm{t} 127 \\
\mathrm{t} 127 \\
\mathrm{t} 127 \\
\mathrm{t} 27 \\
\mathrm{t} 160 \\
\mathrm{t} 127 \\
\mathrm{t} 127 \\
\mathrm{t} 127 \\
\mathrm{t} 127 \\
\mathrm{t} 084\end{array}$ & $\begin{array}{l}\text { SEA+ } \\
\text { SEA+ } \\
\text { SEA+ } \\
\text { SEA+ } \\
\text { SEB+ } \\
\text { SEA+ } \\
\text { SEA+ } \\
\text { SEA+ } \\
\text { SEA+ } \\
\end{array}$ & $\begin{array}{c}\text { sea, seh, selk, selq } \\
\text { sea, seh, selk, selq } \\
\text { sea, seh, selk, selq } \\
\text { sea, seh, selk, selq } \\
\text { sea, seb } \\
\text { sea, seh, selk, selq } \\
\text { sea, seh, selk, selq } \\
\text { sea, seh, selk, selq } \\
\text { sea, seh, selk, selq } \\
\text {, }\end{array}$ & Freiburg (Germany) & y) Ice-cream & Ice-cream & 20 patients (Fetsch et al.,2014) \\
\hline 12 & 5 & $\begin{array}{l}\text { Human } \\
\text { Human } \\
\text { Human } \\
\text { Human } \\
\text { Human } \\
\text { Human }\end{array}$ & $\begin{array}{l}\text { Nasal mucosa of food } \\
\quad \text { handler \#3 } \\
\text { Emesis of patient\#1 } \\
\text { Emesis of patient \#2 } \\
\text { Emesis of patient \#3 } \\
\text { Emesis of patient \#4 } \\
\text { Stool of patient \#3 } \\
\text { Stool of patient \#4 }\end{array}$ & $\begin{array}{l}\text { t701 } \\
\text { t701 } \\
\text { t701 } \\
\text { t267 } \\
\text { t701 } \\
\text { t701 }\end{array}$ & $\begin{array}{l}1 \\
1 \\
1 \\
1 \\
1 \\
1\end{array}$ & $\begin{array}{l}\text { sea, sei } \\
\text { sea, sei } \\
\text { sea, sei } \\
\text { sea, sei } \\
\text { sea, sei } \\
\text { sea, sei }\end{array}$ & Turin (Italy) & Food handler & Seafood salad & 9 patients (Gallina et al.,2013) \\
\hline 18 & 7 & $\begin{array}{c}\text { Food } \\
\text { Food } \\
\text { Food } \\
\text { Human } \\
\text { Human } \\
\text { Human }\end{array}$ & $\begin{array}{l}\text { Raw chicken filled with broccoli } \\
\text { Cooked meat } \\
\text { Meat-iilled pancake } \\
\text { watermelon } \\
\text { Stool sample of patient } \\
\text { Nasal swab of caterer's nose \#1 } \\
\text { Nasal swab of caterer's nose \#2 }\end{array}$ & $\begin{array}{l}\text { t018 } \\
\text { t018 } \\
\text { t018 } \\
\text { t018 } \\
\text { t018 } \\
\text { t018 }\end{array}$ & $\begin{array}{l}\text { SEAt } \\
\text { SEAt } \\
\text { SEAt } \\
\text { SEAt } \\
\text { SEA+ } \\
\text { SEAt }\end{array}$ & $\begin{array}{l}\text { sea, seg, sei } \\
\text { sea, seg, sei } \\
\text { sea, seg, sei } \\
\text { sea, seg, sei } \\
\text { sea, seg, sei } \\
\text { sea, seg, sei }\end{array}$ & $\begin{array}{l}\text { Baden-Wurttemberg } \\
\text { (Southwest Germany) }\end{array}$ & ler & & 12 patients （Johler et al., 2013) \\
\hline 25 & $\begin{array}{l}9 \\
10 \\
11 \\
12 \\
13 \\
14 \\
15 \\
16 \\
17 \\
18 \\
19 \\
20 \\
21 \\
22 \\
23 \\
24 \\
25\end{array}$ & 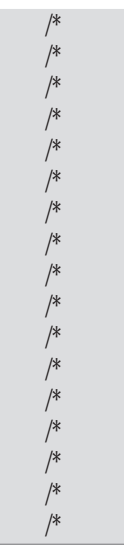 & 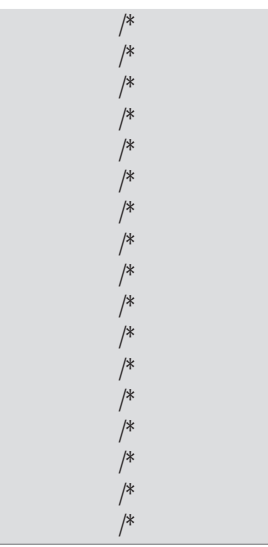 & $\begin{array}{l}\text { t008 } \\
\text { t015 } \\
\text { t018 } \\
\text { t056 } \\
\text { t084 } \\
\text { t648 } \\
\text { t733 } \\
\text { t279 } \\
\text { t4802 } \\
\text { t1239 } \\
\text { t015 } \\
\text { t377 } \\
\text { t383 } \\
\text { t1270 } \\
\text { t6969 } \\
\text { t912 } \\
\text { t056 }\end{array}$ & $\begin{array}{l}p^{*} \\
p^{*} \\
p^{*} \\
p^{*} \\
p^{*} \\
p^{*} \\
p^{*} \\
p^{*} \\
p^{*} \\
p^{*} \\
p^{*} \\
p^{*} \\
p^{*} \\
p^{*} \\
p^{*} \\
p^{*}\end{array}$ & $\begin{array}{l}p^{*} \\
p^{*} \\
p^{*} \\
p^{*} \\
p^{*} \\
p^{*} \\
p^{*} \\
p^{*} \\
p^{*} \\
p^{*} \\
p^{*} \\
p^{*} \\
p^{*} \\
p^{*} \\
p^{*} \\
p^{*} \\
p^{*}\end{array}$ & 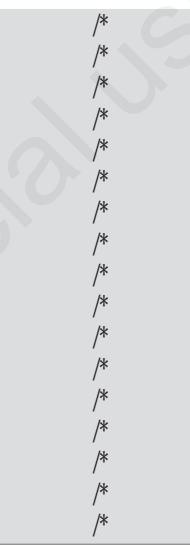 & 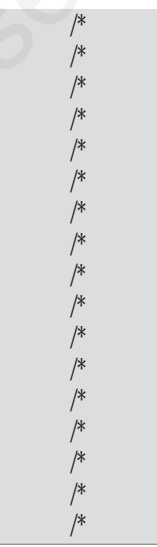 & 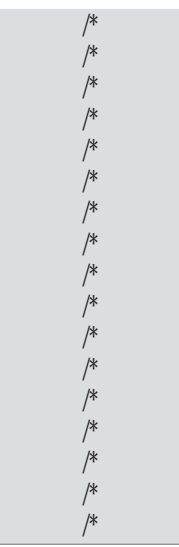 & 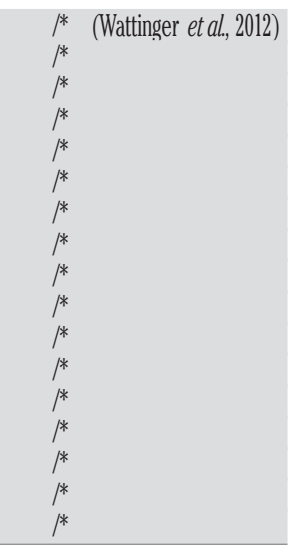 \\
\hline $\begin{array}{l}43 \\
44\end{array}$ & $\begin{array}{l}27 \\
28\end{array}$ & $\begin{array}{l}\text { Food } \\
\text { Food }\end{array}$ & $\begin{array}{l}\text { Cheese isolate \#2 } \\
\text { Cheese isolate\#3 }\end{array}$ & $\begin{array}{l}\text { t018 } \\
\text { t458 }\end{array}$ & $\begin{array}{l}\mathrm{NEG}^{* *} \\
\mathrm{NEG}^{* *}\end{array}$ & $\begin{array}{l}\text { seg, sei, selm, seln, selo, selu } \\
\text { seg, sei, selm, seln, selo, selu }\end{array}$ & $\begin{array}{c}\text { Children and } \\
\text { staff members } \\
\text { at a Swiss boarding } \\
\text { school (Switzerland) }\end{array}$ & $\begin{array}{l}\text { Tomme soft } \\
\text { cheese made } \\
\text { g of raw milk }\end{array}$ & $\begin{array}{l}\text { Tomme soft cheese } \\
\text { made of raw } \\
\text { milk }\end{array}$ & 14 patients (Johler et al., 2015) \\
\hline 45 & $\begin{array}{l}29 \\
30\end{array}$ & $\begin{array}{l}\text { Food } \\
\text { Human }\end{array}$ & $\begin{array}{c}\text { Raw milk isolate } \\
\text { Nasal swab of the dairy owner }\end{array}$ & $\begin{array}{r}\mathbf{t} 2953 \\
\text { t635 }\end{array}$ & $\begin{array}{c}\text { SEA+,SED+ } \\
\text { NEG** }\end{array}$ & $\begin{array}{c}\text { sea, sed } \\
\text { sec, seg, seh, sei }\end{array}$ & Austria & Raw milk & Raw milk & 40 patients (Schmid et al., 2007) \\
\hline 47 & $\begin{array}{l}\mathrm{EI} \\
\mathrm{EI} \\
\mathrm{EI} \\
\mathrm{EI} \\
\mathrm{EI} \\
\mathrm{EI} \\
\mathrm{EI} \\
\mathrm{EI} \\
\mathrm{EI} \\
\mathrm{Er}\end{array}$ & $\begin{array}{l}\text { Food } \\
\text { Food } \\
\text { Food } \\
\text { Food } \\
\text { Food } \\
\text { Environmental } \\
\text { Environmental } \\
\text { Environmental } \\
\text { Environmental } \\
\text { Environmental } \\
\text { Environmental } \\
\text { Environmental } \\
\text { Environmental } \\
\text { Environmental } \\
\text { Environmental }\end{array}$ & $\begin{array}{l}\text { Milk isolate\#1 } \\
\text { Milk isolate \#2 } \\
\text { Milk isolate \#3 } \\
\text { Milk isolate\#4 } \\
\text { Milk isolate \#5 } \\
\text { Milk flask isolate \#1 } \\
\text { Milk flask isolate \#2 } \\
\text { Milk flask isolate \#3 } \\
\text { Milk flask isolate \#4 } \\
\text { Milk flask isolate \#5 } \\
\text { Milk flask isolate \#6 } \\
\text { Milk flask isolate\#7 } \\
\text { Milk flask isolate\#8 } \\
\text { Milk flask isolate \#9 } \\
\text { Milk flask isolate\#10 }\end{array}$ & $\begin{array}{l}\text { t104 } \\
\text { t104 } \\
\text { t104 } \\
\text { t104 } \\
\text { t104 } \\
\text { t104 } \\
\text { t104 } \\
\text { t104 } \\
\text { t104 } \\
\text { t104 } \\
\text { t104 } \\
\text { t084 } \\
\text { t084 } \\
\text { t084 } \\
\text { t084 }\end{array}$ & $\begin{array}{l}\text { SEA+, SED+ } \\
\text { SEA+, SED+ } \\
\text { SEA, SED+ } \\
\text { SEA+, SED+ } \\
\text { SEA+, SED+ } \\
\text { SEA, SED+ } \\
\text { SEA+, SED+ } \\
\text { SEA+, SED+ } \\
\text { SEA, SED+ } \\
\text { SEA+, SED+ } \\
\text { SEA+, SED+ } \\
\text { NEG** } \\
\text { NEG** } \\
\text { NEG** } \\
\text { NEG** }\end{array}$ & $\begin{array}{l}\text { sea, sed, selj, ser } \\
\text { sea, sed, sej, ser } \\
\text { sea, sed, sej, ser } \\
\text { sea, sed, sej, ser } \\
\text { sea, sed, sej, ser } \\
\text { sea, sed, sej, ser } \\
\text { sea, sed, sej, ser } \\
\text { sea, sed, sej, ser } \\
\text { sea, sed, sej, ser } \\
\text { sea, sed, sej, ser } \\
\text { sea, sed, sej, ser } \\
\text { neg** } \\
\text { neg** } \\
\text { neg** } \\
\text { neg** }\end{array}$ & Italy & Milk & Milk & 80 patients \\
\hline
\end{tabular}

SFP, staphylococcal food poisoning; spa, gene encoding staphylococcal protein A; seh, staphylococcal enterotoxin type Hgene; selk, staphylococcal enterotoxin-like type K gene; selq, staphylococcal enterotoxin-like type Q gene; seb, staphylococcal enterotoxin type B gene; sei, staphylococcal enterotoxin type I gene; sed, staphylococcal enterotoxin type D gene; sej, staphylococcal enterotoxin-like type J; ser, staphylococcal enterotoxin type Rgene; seg, staphylococcal enterotoxin type G gene; selm, staphylococcal enterotoxin-like type M gene; seln, staphylococcal enterotoxin-like type N gene; selo, staphylococcal enterotoxin-like type 0 gene; sell, staphylococcal enterotoxin-like type U gene; SEA+, staphylococcal enterotoxin type A positive; SED+, staphylococcal enterotoxin type D positive; NEG**, negative results to phenotypic; neg ${ }^{* *}$, negative results to genotypic. 
breaks in the EU were caused by foodstuffs of animal origin. Fish and fish products were implicated in $10.1 \%$ of all outbreaks. Of the 25 SEs outbreaks, 18 were general outbreaks and seven were household outbreaks (EFSA 2013). Generally, $31.4 \%$ of foodborne outbreaks are due to food prepared in domestic kitchens and $28.6 \%$ in a commercial kitchen or other licensed facilities (EFSA, 2014). As in previous years, in 2012 foodstuffs of animal origin reach the majority of the strong evidence outbreaks, and the most common single foodstuff category reported as food vehicle was eggs and egg products, responsible for 168 outbreaks (22.0\%) (EFSA, 2014). Fish and fish products were responsible for the $9.2 \%$ of all cases. The type of outbreak was provided for 34 cases: 26 (76.5\%) were general outbreaks and eight (23.5\%) were household outbreaks. The most commonly reported settings were restaurant, café, pub, bar, hotel (11 outbreaks), followed by household/domestic kitchen in nine outbreaks (EFSA, 2014). Household outbreaks were also frequent (52.0\%) in Piedmont Region (north-western Italy) (Abelli et al., 2013). The reported cases analysed for their $s p a$-type showed a high heterogeneity of isolates; spa type $t 13252$ resulted correlated in a node of the MST and was never reported as responsible of foodborne outbreak. The most common reported spa types (in three FBO cases) are $t 018$ and $t 084$ (Fetsch et al., 2014; Johler et al., 2013, 2015; Schmid et al., 2007; Wattinger et al., 2012); $t 018$ strain was reported as responsible for the production of SEA in SFP ID, 8 strains isolated in SFP ID 27 resulted negative, and strains responsible for SFP ID 11 reported by Wattinger et al. (2012) lack the genotypic and phenotypic characteristics of the isolate. In this reported case, the SEs con- centrations were comparable to previously reported outbreaks: $0.625 \mathrm{ng} / \mathrm{g}$ of SEA in canned mushrooms (Levine et al., 1996) and $0.45 \mathrm{ng} / \mathrm{g}$ of SEE in cheese (Ostyn et al., 2010a). In this case, an average meal might be around $100 \mathrm{~g}$, and $50 \mathrm{~g}$ of this may be represented by home-canned tuna fish. Considering the level of combined revealed toxins (2.5 $\mathrm{ng} / \mathrm{g}$ ), the intake may be $125 \mathrm{ng}$ comparable to estimated human dose (around $144 \mathrm{ng}$ ) of SE from a large outbreak of SFP involving chocolate milk in a school district (Evenson et al., 1988).

\section{Home-canning procedure}

The tuna was boiled in salted water for about one hour and then cooled in an uncovered container at room temperature for 12 hours. The meat chunks were added and compacted in nine glass jars (about $400 \mathrm{~mL}$ volume) by hand and then coated with corn oil and olive oil. The jars were then closed and placed in boiling water for 30 minutes. The family received it one week before the meal and stored it at room temperature. The jar was opened just before eating and tuna was put in a dish plate.

Contamination during post-cooking and handling, especially putting the meat chunks in jars, was suspected as the possible source of this food poisoning incident. Inadequate final heat treatments in home-canning may allow $S$. aureus cells to survive and produce SEs in food products, including those preserved in oil. SEs are able to retain some biological activity after heat treatment at $121^{\circ} \mathrm{C}$ for 28 minutes. The decimal reduction (D-value) for $S$. aureus at $60^{\circ} \mathrm{C}$ has been reported as 4.8-6.6 minutes in broth as compared with 20.5 minutes when encapsulated in fish and oil (Paulin et al.,
2012). Additional evidences for contamination during food handling in the post-cooking phase as the most likely cause are finding of preformed SEA and SED and of enterotoxigenic strain carrying the relative encoding genes (sea and sed) in the home-canned tuna.

\section{Conclusions}

The lack of information regarding hand wounds among the family of patients and microbiological contamination of utensils used for cooking and serving is the limit of the study. Likewise, a food-handler was the most likely common source of an SFP gastroenteritis occurring in 2011 in Turin, Italy, following a catered dinner party at a private home (Gallina et al., 2013). This investigation was unable to discover the exact source of the $S$. aureus or the enteroxins because it was not possible to take nasal or skin swab samples from any of the family members or the utensils used for cooking and serving. Furthermore, spoilage of homemade conserves can result from contamination by food handlers themselves and a lack of knowledge of proper and good practices. The high incidence of domestic outbreaks underlines the importance of risk communication and dissemination of home-canning guidelines to raise awareness for and to reduce the risk of foodborne diseases and outbreaks. Consumers become ill from food consumed at home, which is an important place of consumption for tracing the source of foodborne pathogens, the origin and the typing of responsible isolates. However, apart from identifying the location and the level of the contamination of homemade foods, the exact point for

Table 2. Analysis performed and results in food and strain typing.

\begin{tabular}{|c|c|c|c|c|}
\hline \multicolumn{2}{|c|}{$\begin{array}{l}\text { Food sample analysis } \\
\text { SE analysis }\end{array}$} & \multicolumn{2}{|c|}{$\begin{array}{l}\text { Isolated strain analysis } \\
\text { Phenotypic }\end{array}$} & $\begin{array}{l}\text { Genotypic } \\
\text { ses mPCR }\end{array}$ \\
\hline \multirow[t]{11}{*}{ Positive } & SEA $2.64 \mathrm{ng} / \mathrm{mL}$ in $25 \mathrm{~g} / \mathrm{mL}$ & NHS type 1 & New spa-type $t 13252$ & sea detected \\
\hline & SEB $<\mathrm{LoQ} n \mathrm{~g} / \mathrm{mL}$ in $25 \mathrm{~g} / \mathrm{mL}$ & & & seb not detected \\
\hline & SEC $<\mathrm{LoD} \mathrm{ng} / \mathrm{mL}$ in $25 \mathrm{~g} / \mathrm{mL}$ & & & sec not detected \\
\hline & SED $\quad 11.03 \mathrm{ng} / \mathrm{mL}$ in $25 \mathrm{~g} / \mathrm{mL}$ & & & sed detected \\
\hline & & & see not detected & \\
\hline & & & seg detected & \\
\hline & & & seh not detected & \\
\hline & & & sei detected & \\
\hline & & & selj detected & \\
\hline & & & sep not detected & \\
\hline & & & ser detected & \\
\hline
\end{tabular}

SE, staphylococcal enterotoxins; ELISA, enzyme-linked immunosorbent assay; spa, gene encoding staphylococcal protein A; ses, staphylococcal enterotoxins; mPCR, multiplex polymerase chain reaction; SEA, staphylococcal enterotoxin type A; SEB, staphylococcal enterotoxin type B; SEC, staphylococcal enterotoxin type C; SED, staphylococcal enterotoxin type D; LoQ, limit of quantification; LoD, limit of detection; NHS, not hos specificity; sea, staphylococcal enterotoxin type A gene; seb, staphylococcal enterotoxin type B gene, sed, staphylococcal enterotoxin type D gene; see, staphylococcal enterotoxin type E gene; seg, staphylococcal enterotoxin type G gene; seh, staphylococcal enterotoxin type H gene; sei, staphylococcal enterotoxin type I gene; sej, staphylococcal enterotoxin-like type J gene; sep, staphylococcal enterotoxin type Pgene; ser, staphylococcal enterotoxin type R gene. 
addressing the guidelines also for small productions should be pinpoint to better identify the causes of illness and to allocate resources in a risk-based manner.

\section{References}

Abelli G, Barbaro A, Biorci F, Caputo M, Carraro E, Costa A, Cravero M, Decastelli L, Demicheli V, Ferrari P, Gilli G, Griglio B, Golzio F, Marro S, Maurella C, Negro M, Rossi MV, Serra R, Tiberti D, Vencia W, 2013. Sorveglianza delle malattie trasmesse da alimenti. Available from: http://www.regione.piemonte.it/sanita/cms 2/alimenti/sorveglianza-delle-malattietrasmesse-da-alimenti

Bianchi DM, Ingravalle F, Adriano D, Gallina S, Gramaglia M, Zuccon F, Astegiano S, Bellio A, Macori G, Ru G, Decastelli L, 2014. Reproducibility study for the detection of staphylococcal enterotoxins in dairy products between official Italian national laboratories. J Food Protect 77:999-1004.

CDC, 1998. Botulism in the United States, 1899-1966. Centers for Disease Control and Prevention, Atlanta, GA, USA. Available from: http://www.cdc.gov/botulism/

Devriese LA, 1984. A simplified system for biotyping Staphylococcus aureus strains isolated from animal species. J Appl Bacteriol 56:215-20.

EFSA, 2013. The European Union summary report on trends and sources of zoonoses, zoonotic agents and food-borne outbreaks in 2011. EFSA J 11:1-3129.

EFSA, 2014. The European Union summary report on trends and sources of zoonoses, zoonotic agents and food-borne outbreaks in 2012. EFSA J 12:1-3547.

Evenson ML, Hinds MW, Bernstein RS, Bergdoll MS, 1988. Estimation of human dose of staphylococcal enterotoxin A from a large outbreak of staphylococcal food poisoning involving chocolate milk. Int J Food Microbiol 7:311-6.

Feng C, Teuber S, Gershwin ME, 2016.
Histamine (scombroid) fish poisoning: a comprehensive review. Clin Rev Allerg Immu 50:64-9.

Fetsch A, Contzen M, Hartelt K, Kleiser A, Maassen S, Rau J, Kraushaar B, Layer F, Strommenger B, 2014. Staphylococcus aureus food-poisoning outbreak associated with the consumption of ice-cream. Int J Food Microbiol 187:1-6.

Gallina S, Bianchi DM, Bellio A, Nogarol C, Macori G, Zaccaria T, Biorci F, Carraro E, Decastelli L, 2013. Staphylococcal poisoning foodborne outbreak: epidemiological investigation and strain genotyping. $\mathrm{J}$ Food Protect 76:2093-8.

Harmsen D, Claus H, Witte W, Rothgänger J, Claus H, Turnwald D, Vogel U, 2003. Typing of methicillin-resistant Staphylococcus aureus in a university hospital setting by using novel software for spa repeat determination and database management. J Clin Microbiol 41:5442-8.

ISO, 1999. Microbiology of food and animal feeding stuffs: horizontal method for the enumeration of coagulase-positive staphylococci (Staphylococcus aureus and other species). Part 2: technique using rabbit plasma fibrinogen agar medium. ISO Norm 6888-2:1999. International Standardization Organization ed., Geneva, Switzerland.

Johler S, Tichaczek-Dischinger PS, Rau J, Sihto HM, Lehner A, Adam M, Stephan R, 2013. Outbreak of staphylococcal food poisoning due to SEA-producing Staphylococcus aureus. Foodborne Pathog Dis 10:777-81.

Johler S, Weder D, Bridy C, Huguenin MC, Robert L, Hummerjohann J, Stephan R, 2015. Outbreak of staphylococcal food poisoning among children and staff at a Swiss boarding school due to soft cheese made from raw milk. J Dairy Sci 98:2944-8.

Lamand V, Dauwalder 0, Tristan A, Casalegno JS, Meugnier H, Bes M, Dumitrescu 0, Croze M, Vandenesch F, Etienne J, Lina G, 2012. Epidemiological data of staphylococcal scalded skin syndrome in France from 1997 to 2007 and microbiological characteristics of Staphylococcus aureus associ- ated strains. Clin Microbiol Infec 18:51421.

Levine WC, Bennet RW, Choi Y, Henning KJ, Rager JR, Hendricks KA, Hopkins DP, Gunn RA, Griffin PM, 1996. Staphylococcal food poisoning caused by imported canned mushrooms. J Infect Dis 173:1263-7.

McCarthy S, Bjornsdottir-Butler K, Benner R $\mathrm{Jr}, 2015$. Storage time and temperature effects on histamine production in tuna salad preparations. J Food Protect 78:13439.

Ostyn A, De Buyser ML, Guillier F, Groult J, Felix B, Salah S, Delmas G, Hennekinne JA, 2010a. First evidence of a food poisoning outbreak due to staphylococcal enterotoxin type E, France, 2009. Euro Surveillance 15:1-4.

Ostyn A, Prufer AL, Papinaud I, Hennekinne JA, 2010b. Detection of staphylococcal enterotoxins types SEA to SEE in all types of food matrices. European screening method of the EU-RL for coagulase-positive staphylococci, including Staphylococcus aureus. Version 5. Anses Laboratory for Food Safety, Maisons-Alfort, France.

Paulin S, Horn B, Hudson JA. Factors affecting growth and inactivation of $\mathrm{S}$. aureus and enterotoxin production. Available from: http://www.foodsafety.govt.nz/elibrary/indu stry/factors-staphylococcal-enterotoxindairy.pdf

Schmid D, Fretz R, Winter P, Mann M, Höger G, Stöger A, Ruppitsch W, Ladstätter J, Mayer N, de Martin A, Allerberger F, 2007. Outbreak of staphylococcal food intoxication after consumption of pasteurized milk products, June 2007, Austria. Wien Klin Wochenschr 121:125-31.

Wattinger L, Stephan R, Layer F, Johler S, 2012. Comparison of Staphylococcus aureus isolates associated with food intoxication with isolates from human nasal carriers and human infections. Eur J Clin Microbiol 2012 31:455-64.

Wilson BJ, Musto RJ, Ghali WA, 2012. A case of histamine fish poisoning in a young atopic woman. J Gen Intern Med 27:878-81. 